\title{
Diversity Status and Traditional Uses of Pearl Millet in Benin Northern
}

\section{Kifouli ADEOTI1,2, Gustave DJEDATIN³, Ebenezer EWEDJE4, Fatiou TOUKOUROU1,2, Farid BABA-MOUSSA ${ }^{1,2}$}

\begin{abstract}
${ }^{1}$ LAMITA, Faculté des Sciences et Techniques, Département de Biologie végétale, Université d'Abomey-Calavi (UAC), Bénin

${ }^{2}$ Equipe Biodiversité et Ecologie des plantes, Faculté des Sciences et Techniques, Département de Biologie végétale, Université d'Abomey-Calavi (UAC), Bénin

${ }^{3}$ Laboratoire de Biologie moléculaire et de Bioinformatique Appliquée à la génomique ; Faculté des Sciences et Techniques de Dassa Zoumè, Université Nationale des Sciences, Technologies, Ingénieries et Mathématiques (UNSTIM), Bénin

${ }^{4}$ Laboratoire de Biologie, Ecologie végétale appliquée et de génétique forestière; Faculté des Sciences et Techniques de Dassa Zoumè; Université Nationale des Sciences, Technologies, Ingénieries et Mathématiques (UNSTIM), Bénin
\end{abstract}

\begin{abstract}
Millet is an important cereal crop in the northern Benin. However, the diversity level of cultivated varieties still remain unknown. In order to document the diversity of cultivated species, the vernacular names, the geographical distribution of cultivated varieties, the traditional cultural practices, the uses and the farmers' preferences related to millet cultivation, 52 villages were randomly selected and surveyed throughout the northern part of Benin using the participatory research appraisal. A total of twenty two vernacular names were recorded. Results from our survey showed that farmers cultivated both earlier and later varieties. The level of diversity is very low and the number of varieties cultivated varied from one to a maximum of three. Farmers primarily cultivated millet to fill household needs. However, productivity and culinary qualities appeared to be the most preferences criteria which determined the choice of cultivated variety. Both men and women are involved in millet "cultivation. Men are mostly in charge of hard work and women are mainly involved in harvesting and post-harvest. With the nmber of vernacular names recorded it is clearly recommended to clarify the reel level of diversity of cultivated millet through agromrophological and genetic characterization.
\end{abstract}

Keywords: Cereal; Pennisetum, On-Farm Diversity, Preferences Criteria

\section{Introduction}

Cereals occupy a large place among cultivated plants. An average of 690 million hectares of cereals are grown in the world, accounting for more than $15 \%$ of the world's agricultural area (USDA, 2010/2011).

The main cereal crops in the world are maize, wheat, rice, sorghum, millet. In Africa, millet production ranks third after maize and sorghum (FAO, 2015). Despite Africa remain the center of origin and production of many different cereals, yields are often less than half the world average (Macauley et Ramadjita, 2015). This leads to an improvement of existing species to meet production constraints, and the search for new highly productive varieties. West Africa is the leading producer of millet. Although located in West Africa, Benin is a small producer of millet. It is mainly grown in the northern part of
Benin and ranks the fourth after maize, rice, and sorghum (USDA 2013). Because of its good performances in low-fertility soils, it is an important staple cereal cultivated in regions severely affected by malnutrition. It has a high nutritional value compared to others cereals and presents therefore a high potential in contributing to food and nutrition security (Vanisah et al., 2011). In the northern part of the Benin, pearl millet contributes to the daily food supply through the consumption of local porridge, cake and traditional beverage. Unfortunately, cultivated varieties, traditional knowledge and uses remain undocumented.

At the international level, actions to preserve and adapt genetic resources to climate change have been initiated in recent years. These various actions are preceded by an inventory of wild and cultivated

This article is published under the terms of the Creative Commons Attribution License 4.0

Author(s) retain the copyright of this article. Publication rights with Alkhaer Publications.

Published at: http://www.ijsciences.com/pub/issue/2017-08/

DOI: 10.18483/ijSci.1399; Online ISSN: 2305-3925; Print ISSN: 2410-4477 
varieties species and the different utilizations made by the local populations. At this time there is no national collection of pearl millet landraces from Benin and moreover, very little information is available on the diversity of cultivated pearl millet accessions in the Northern part of the country. Similar research had been conducted on some crop such as leafy vegetables, sorghum, maize and others (Dansi et al., 2008; Adeoti et al., 2009). The present study was undertook to make a state-of-art of cultivated variety of pearl millet, to document the endogenou knowledge related to the varieties, the constraints related to production, the farmer's preference and the different modes of processing and consumption.

\section{Material and methods \\ Sudy of area}

The present study was conducted in the northern part of Benin, a country located in the west Africa. The Northern region is located in arid and semi-arid agroecological zones characterized by unpredictable and irregular rainfall oscillating between 800 and 950 $\mathrm{mm} /$ year. The annual mean temperatures range from 26 to $28^{\circ} \mathrm{C}$ and may exceptionally reach 35 to $40^{\circ} \mathrm{C}$ in the far Northern localities. In this part of country we have a tropical climate characterized by one rainy season from May to October and one dry season from November to April (Akoègninou et al., 2006; Vissin, 2007). The northern is mainly characterized by the tropical ferruginous soils with some enclaves of ferrallitic soils and vertisols. The northern is bordered by the Republic of Niger and the Republic of Burkina Faso and contaied 4 districts which are Alibori, Borgou in the east and Atacora, Donga in the west. A total of fiftheen ethnic groups corresponding to an average of $34 \%$ of population were surveyed.

\section{Sites selection and survey}

Survey was conduced across cultivated areas. The number of villages varies from one region to another and present different agroecological characteristics. A total of 52 villages belonging to different ethnical groups were randomly selected and surveyed. Data were collected through different villages and ethnical groups by the application of Participatory Research Appraisal tools and techniques such as group discussions, individual interviews using a questionnaire according to Adoukonou-Sagbadja et al. (2006) Dansi et al. (2008) and Adeoti et al. (2009). Interviews were conducted with the help of interpreters from each ethnic group. Figure 1 shows the distrbution of selected area of study.

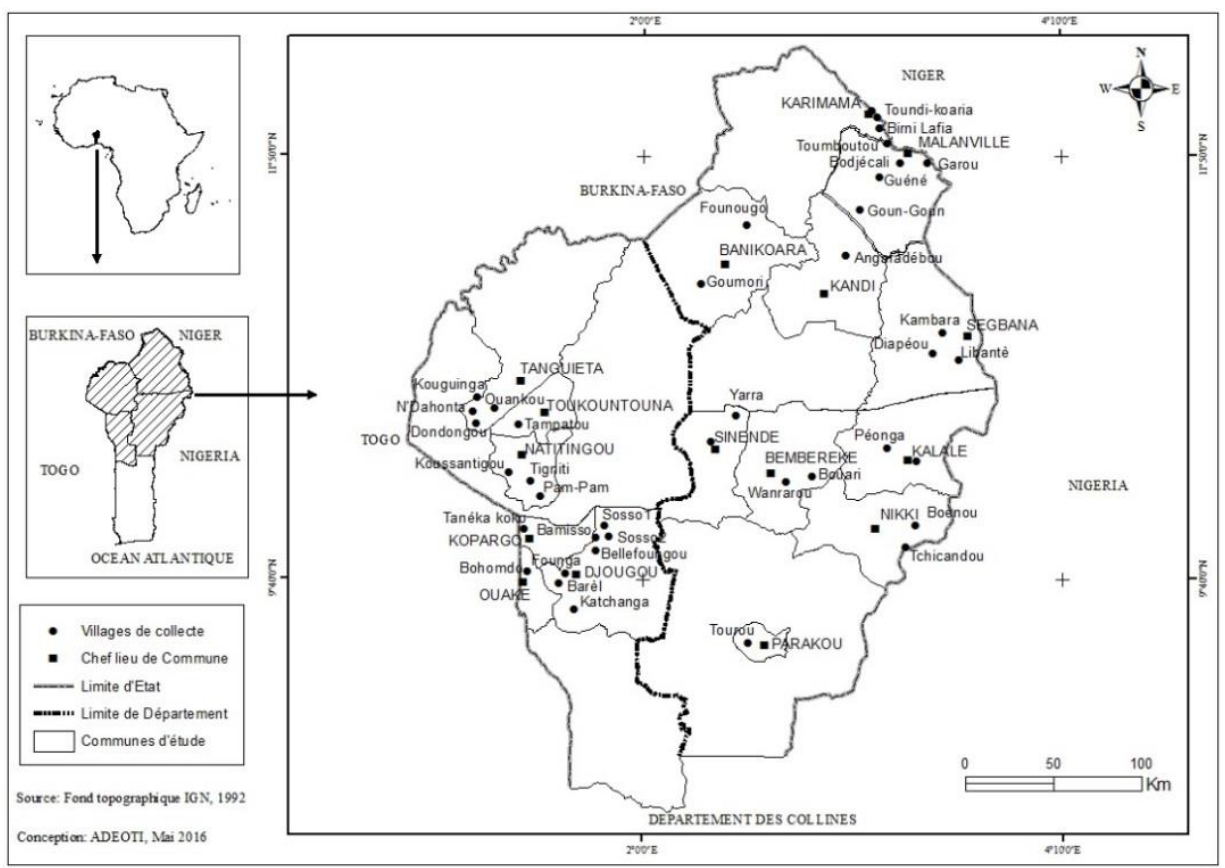

Figure 1: Geographical distribution of villages across study areas

\section{Data analysis}

Data analysis was performed using descriptive statistics. Frequencies, percentages, means were calculated using the Microsoft excel and used to generate table and figures. The software MapInfo Professional 8.0 was used to draw the geographical distribution of surveyed villages.
Results \& Discussion

Origin, vernacular names, and diversity of cultivated pearl millet

Pearl millet is one of the important cereals cultivated in the north part of Benin. According to the farmers where surveyed has been conducted cultivation of millet begun since a lot of years with their forefathers and considered it as an endogenous crop in the 
department of Ataco-Donga. In the northeast, some popoulations revealed that millet has been introduced by the haoussa and djerma people who came from Niger and Nigeria. Indeed, this part of country is a frontier district with these two countries which are the big producers of millet. Moreover the two countries share with Benin certains ethnic group who lives in these region.

A total of 112 accessions were collected across villages and ethnic groups surveyed. For all the accessions collected, 22 vernacular names have been recorded and vary across ethnic groups. Table 1 presents the list of vernacular names recorded for accessions. The different names used were related to aspect of variety, earless, drought tolerance, color of grains and flour. There is a very low variability of names within the same ethnic group. Only for the Ditemmari, Lokpa and Wama ethnic groups for which 2 to 3 names have been registered and which represent different varieties within the same ethnic group. For example, for the lokpa ethnic group, Amala Kouhouloumè and Amala koukpêtè designate varieties whose grains are respectively white and black. Similar observations have also been reported for other plants for which vernacular names have been accompanied by a suffix or prefix to designate a distinctive aspect of the plant. This is the case for some leafy vegetables (Adéoti et al., 2009, Zakaria et al., 2017), cereals such as fonio, sorghum (Adoukonou-Sagbadja et al., 2008, Dossou-Aminon et al., 2014a). However in some cases identical names are used by different ethnic groups. This is the case of the vernacular name yomaga used by the Wama, Naténi, Natimba and zokpera used by the ethnic groups Yom and Naténi. Although 22 vernacular names have been recorded, the low number of varieties grown throughout the villages could reflect the low level of varietal diversity. Figure 2 shows the diversity of millet grain collected from surveyed area. Indeed grains vary by form, aspect, largeness and color.

Our analysis revealed that there are a very low diversity of pearl millet cultivated across area of study. Many farmers grow millet but on mediumsized areas using one or two varieties. Contrary to sorghum, the diversity level is very low. The number of variety cultivated per household or per farmer varies from one (1) to three (3). Two types of varieties are cultivated, the late varieties and early varieties. According to farmers interviewed, late varieties have 6 to 7 months grown while for early varieties cycles ranging from 3 to 4 months are observed. The high number of variety cultivated was found at libantè from the department of Alibori in the northeast. The low level of diversity observed could be related to many factors such as eating habits, postharvest transformations. Indeed, millet ranks the third among cereal in term of consumption after sorghum and maize in the surveyed area. The different uses of post-harvest crops could probably influence strongly the choice of cultivated varieties on the one hand and the area sown on the other hand. According to the farmers, the low markettable value and the low selling contributed also to the reduction of the number of varieties across household. For majority of respondents, millet was cultivated firstly to satisfy family needs. Beyond the use as food product, millet is also used during traditional ceremony. It is essentially observed in the department of atacoradonga. Seven varieties (under clarification of name synonymy) eyomate, diyemarie, amala kouhoulomè, maïwari, sowawia, yomage and zokpéra were found to be used for traditional ceremonies. The variety called iyaku, could stimulate through consumption milk production for wet nurse. Indeed it is highly consumed by wet nurse across mokole ethnic group in the department of borgou-alibori. 


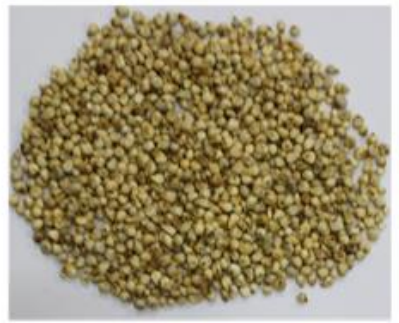

Amala kouhoulomè

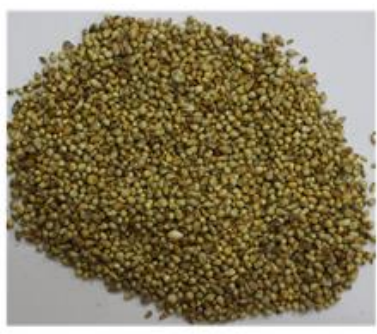

Hinnintchire

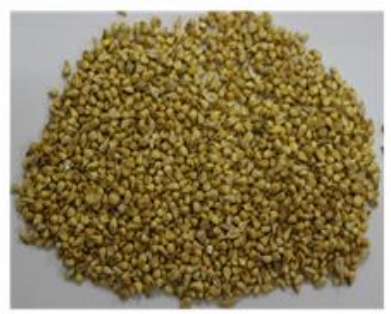

Sonna

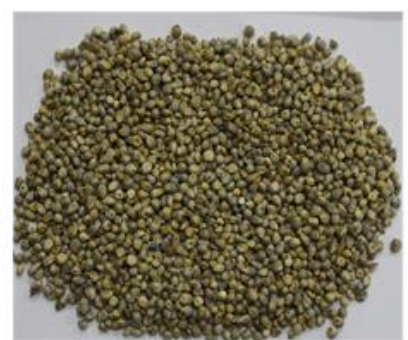

Gbeï

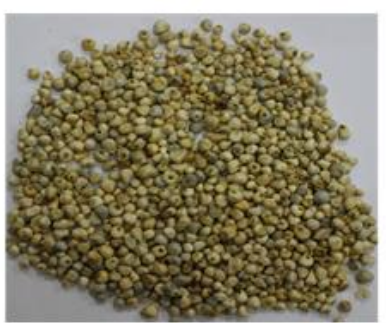

lyaku

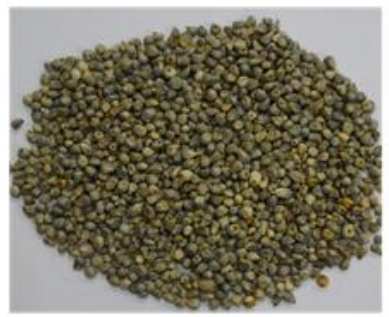

Zokpera

Figure 2: Diversity of millet grains collected form Benin'northern

Table 1: List of vernacular names and corresponding ethnic group

\begin{tabular}{cll}
\hline $\mathrm{N}^{\circ}$ & Vernacular names & Ethnic group \\
\hline 1 & Amala Kouhouloumè & Lokpa \\
2 & Amala koukpètè & Lokpa \\
3 & Diyématrie & Otammari \\
4 & Emadè & Ditemmari \\
5 & Eyomata & Ditemmari \\
6 & Maïwari & Ditemmari \\
7 & Nari & Peulh \\
8 & Sowabiya & Wama \\
9 & Sowaya & Wama \\
10 & Yomaga & Wama, Naténi, Natimba \\
11 & Zokpéra & Yom, Naténi \\
12 & Guero & Ahoussa, Peulh \\
13 & Gbeï & Bariba \\
14 & Wea & Boo \\
15 & Sonna & Dendi \\
16 & Meïwaré & Gando, Peulh \\
17 & Somnon & Germa \\
18 & Hinnitchiré & Germa, Dendi \\
19 & Idié & Gourmantché \\
20 & Iyasè & Mokolé \\
21 & Iyaku & Mokolé \\
22 & Eyo-mata & Otamari \\
\hline
\end{tabular}




\section{Different utilization of pearl millet and preference criteria}

Pearl millet is used on the same way like others cereals such as maize, sorghum, rice across surveyed areas. However, its frequency of use and consumption and activities related to its transformation on the other hand, vary from the northeast area to the northwest and across ethnic group. Indeed, the use of millet for preparation of porridge rank the first in the northeast $(60 \%$ of responds) follow by mash flour, and a traditional local food so called foura which is a mixture of millet' couscous and cow milk. Another mode of use which ranks the second is the fermented porridge daily consumed by children.

For the preferences criteria which are related to the choice and maintenance of one variety at the household level, eight (08) criteria were recorded. The most important criteria that received the maximum of opinions with $100 \%$ of respondents were productivity and culinary quality. In fact, productivity is the first criterion indicated by farmers for any crop.

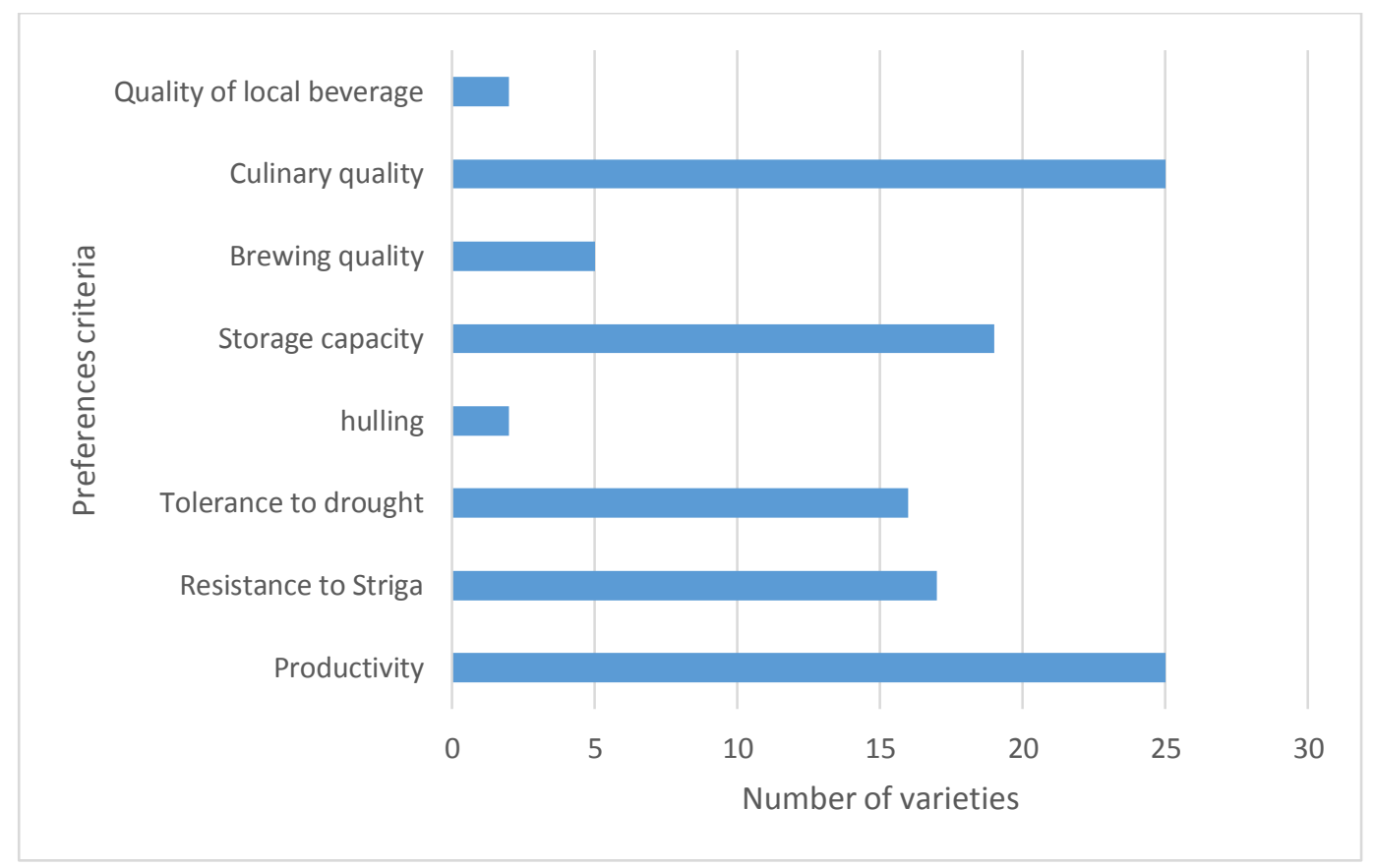

Figure 3: Number of variety identified per preference criteria across area of study

\section{Gender role}

As with most of crops, women and men are involved in millet production. Activities related to millet production can be divided into two categories such as on-farm and post-harvest activities. Figue 3 presents the percentage of each sex involved in the cultivation of pearl millet. However, the distribution of tasks is fairly well defined. For on-farm activities, across all ethnic group and cultivated areas surveyed, farm'owner where pearl millet is cultivated are men. Nevertheless, activity related to its production are distributed between men and women at the household level. Men are mainly engaged in plowing, farm management, storing into the garret. Similar results were reported for other crops production such as sorghum, maize, groundnut, pepper, fonio (DossouAminon et al., 2014b; Adoukonou-Sagbadja et al., 2008; Missihoun et al., 2012). Indeed, ploughing' activity requires a lot of energy and can not be entrusted to women according to farmer. An average of $85.5 \%$ of men are involved in the plowing activities. This result shows that plowing activities are mainly dominated by men and confirmed the previous reported by some authors (King, 2016; Shoo, 2011). Beyond plowing activities, men are in the majority involved in the others on-farm activities such as weeding, application of fertilizer and farm management in general. For this category, variety selection, seeds treatment and the choice of variety to be cultivated are dominated by women. Only sowing and harvesting requires both men and women in majority and represent respectively $62.34 \%$ and $55.74 \%$ of responses. On the other hand, activities related to sowing, and weeding of the field are often carried out by both men and women and sometimes the whole family is requested.

For post-harvest activities, its appears clearly that women are mainly involved in harvesting and postharvest activities such as processing and sales. Beyond the storage in the garret, the almost totality of post-harvest activities are dominated by women. 
Indeed, women transport panicles from field to home and then men take relay to store for storing into the garret. This result could be explained by some aspects related to the garret such as the form, the height and the facility to access into the garret, which are factors that affect the hardness of access by women. However, some cases of sale on the market by a few men were also observed. Contrary to the others activities, transformation of grain is exclusively women tasks $(100 \%)$. There is no man involved in that activity. Contrary to the results (Adhikari 2012; RESMISA 2012), women assume over 90 percent of workload in millet cultivation.

Table 2 : Implication of men and women in on-farm ad post harvest activities of pearl millet

\begin{tabular}{llll}
\hline Activities/ task related to the chain production of pearl millet & Men & Women & Both \\
\hline Plowing (labour) & 85.5 & 7.25 & 7.25 \\
Seeds sowing & 19.56 & 18.1 & 62.34 \\
Application of fertilizer & 58.31 & 18.41 & 23.28 \\
Variety selection & 41.98 & 47.55 & 10.47 \\
Harvesting & 13.67 & 30.59 & 55.74 \\
Weeding & 65.83 & 20.35 & 13.82 \\
Seeds treatment & 15.67 & 68.92 & 15.41 \\
Choice of variety to be cultivated & 41.13 & 42.35 & 16.52 \\
Farm management & 72.67 & 8.98 & 18.35 \\
Transport of panicle from field to home & 14.27 & 49.77 & 35.96 \\
Storage of panicle/grain into the garret & 67.47 & 17.15 & 15.38 \\
Treshing of grain & 12.63 & 52.16 & 35.21 \\
Cleaning of grain & 13.91 & 58.13 & 27.96 \\
Dry of grain & 10.43 & 55.76 & 33.81 \\
Selling of grain & 16.99 & 61.37 & 21.64 \\
Transformation of grain (porridge, beverage, etc.) & 0.00 & 100.00 & 0.00 \\
\hline
\end{tabular}

\section{Contraints related to millet production}

As for most of crops, several constraints impeded pearl millet production. The main factor that affects the production are biotic and abiotic factors. Among abiotic factors we noticed irregularity of rains, accentuation of drought.

Among the abiotic factors, we noticed the irregularity of the rains, the intensification of the drought, the decrease of the yields linked to the poverty of the soils and the non-availability of the varieties adapted to the different variations registered. Indeed, these different constraints encourage farmers to turn to other alternatives, such as the search for droughttolerant varieties, early-maturing varieties with a better yield. Biotic factors are mainly related to stock insects and heavy pressure of birds on farm that are the real devastating of fields. However, the first constraint evoked by the peasants is the irregularity of the rains followed by the length of the drought. This change in the seasonal length due to climate changes is well known by peasants and have also been reported for cultivation of yam (Loko et al., 2013) , sorghum (Dossou-Aminon et al., 2014a), cassava (Kombo et al., 2012)

\section{Discussion}

Food security remains a major problem in the developing countries. This involves improving crop yields, developing new varieties and cultivating species adapted to climate change. However, the development and improvement of plant species cannot be done without an inventory of existing species. Millet is recognized for cultivation in arid regions and is a species contributing to the improvement of the nutritional status of children. Despite this great nutritional importance, our results have shown, subject to synonymy, that the level of diversity is very low, contrary to the diversity observed for other cereals such as sorghum, maize (Dossou-Aminon et al.,2014a,b; Quenum et al., 2017). The morphological diversity of grains showed in figure 2 indicated probaly the existence of genetic variability. Although the vernacular names attributed are different from one ethnic group to another, they could designate the same varieties. Similar cases have been reported in fonio, leafy vegetables, voandzou, maize, and other crops (Adoukonou-Sagbadja et al., 2006; Batawila et al., 2007; Mekbib,2007;Dansi et al., 2009b; Kombo et al., 2012).Unlike millet, sorghum was recorded in the northeastern region, with the number of cultivated varieties varying from 1 to 10 with an average of 4 per village (DossouAminon et al., 2014a,b; Missihoun et al., 2012). The low level of diversity recorded among houselhod could be also related to the low profitability of pearl millet according to farmers. Indeed, King (2016) also reported that the low profitability of millets in cash is one of the reason that leads people to neglect it and confine it just for family needs, which constitutes a brake on trade between peasants. 
Analysis of the involvement of men and women in the pearl millet production in the northern Benin, clearly showed that women play a significant role in post-harvest operation contrary to men who are involved in on-farm activities. However in India, women are predominant at every stage in millet production (King 2016). The role of gender in farm structure and crop production varies from region to another and sometimes across ethnic groups. For example, in Burkina farm work is conducted under the authority of the household head (Van den Broek, 2009; Guirkinger and Platteau, 2014; Theriault et al., 2017). Indeed, in the northern region of the country, women have very little power in decision-making concerning rural activities. This is why the harvesting and post-harvest activities considered as secondary are often dedicated to them. This is contrary to what is observed in the south Asia where women provide 90 percent of the labour for cultivating rice (UNFPA, 2002; Shoo, 2011) and Kenya and Tanzania where women are the primary responsibles for farming (Hyder et al., 2005).

The transformation activities are related to the eating habits of the different ethnic groups surveyed. In general, millet is used as a substitute for sorghum and maize. However in the northeast the processing products mainly are millet'mash eat with leafy vegetable, millet couscous, and porridge. In addition to these products it is also used for the production of the local drink consumed in the northwest which represent the cultural identity of ethnic group living in the northwest. However the use for beverage rank the last position among preference criteria because sorghum is the cereal usually use for local beverage production. In general, most of preferences criteria registered were also found for sorghum and other cereals (Dossou-Aminon, 2014b; King, 2016).

\section{Conclusion}

This study permitted to have an update overview on the cultivation and the status of Pearl millet in Benin northern. Indeed, millet still remain an orphan crop compared to maize, sorghum and rice. Our results showed that the level of diversity among cultivated pearl millet is very low. Despite the twenty two vernacular names recorded, in most of villages and households, one to two varieties were cultivated. Varieties are primarily cultivated for household food security and livelihoods and in some cases for their social and cultural needs. However, it appears important to clarify the real level of diversity among cultivated varieties of millet. On the other hand climate change is an important factor that affects the production of millet in the north. The search of varieties adapted to climate change and which answer peasant's expectation could improve millet production.
Conflict of interest: The authors declare that they have no conflict of interest

Acknowledgments: Authors would like to thank the IFS through the grant No C/5680-1 gives to the first author.

\section{References}

1. Adéoti, K., Dansi, A., Ahoton, L., Kpèki, B., Vodouhè, R. Ahantchédé, A., Ahohuendo, B., Hounhouigan, J., Sanni, A. (2009). Selection of sites for the in situ conservation of four traditional leafy vegetables (Ceratotheca sesamoides, Sesamum radiatum, Acmella uliginosa and Justicia tenella) consumed in Benin. International Journal of Biological and Chemical Sciences, 3 (6): $1357-1374$. https://doi.org/10.4314/ijbcs.v3i6.53156

2. Adoukonou-Sagbadja, H., Dansi, A., Vodouhè, R., Akpagana, K. (2006). Indigenous knowledge and traditional conservation of Fonio millet (Digitaria exilis Stapf, Digitaria iburua Stapf) in Togo. Biodiversity and Conservation, 15: 2379-2395. https://doi.org/10.1007/s10531-004-2938-3

3. Batawila, K., Akpavi, S., Wala, K., Kanda, M., Vodouhè, R., Akpagana, K. (2007). Diversité et gestion des légumes de cueillette au Togo. AJFAND, 7 (3): 1-16.

4. Dansi, A., Adjatin, A., Adoukonou-Sagbadja, H., Adomou, A., Faladé, V., Yedomonhan, H., Akpagana, K., de Foucault, B. (2009a). Traditional leafy vegetables in Benin: Folk nomenclature, species under threat and domestication. Acta $\begin{array}{llll}\text { Botanica } & \text { Gallica, } & 156 & \text { (2): }\end{array}$ https://doi.org/10.1080/12538078.2009.10516150

5. Dansi, A., Adjatin, A., Adoukonou-Sagbadja, H., Faladé, V., Yédomonhan, H., Odou, D., Dossou, B. (2008). Traditional leafy vegetables and their use in Benin Republic. Genetic Resources and Crop Evolution, 55: 1239-1256. https://doi.org/10.1007/s10722-008-9324-z

6. Dansi, A., Adoukonou-Sagbadja, H., Vodouhè, R., (2009b) Diversity, conservation and related wild species of Fonio millet (Digitaria spp.) in the northwest of Benin. Genetic Resources and Crop Evolution 3(6):1357-1374. https://doi.org/10.1007/s10722-009-9522-3

7. FAO, 2015. Protection sociale et agriculture: Briser le cercle vicieux de la pauvreté rurale.

8. Guirkinger, C., Platteau, J.P. (2014). The effect of land scarcity on farm structure: Empirical evidence from Mali. Economic Development and cultural change, 62 (2), 195-238. https://doi.org/10.1086/674340

9. Hyder, A.A, Maman, S., Nyoni, J.E, Khasiani, S., Teoh, N., Premji, Z., (2005). The pervasive triad of food security, gender inequity and women's health: explaratory research from subSaharan Africa. African Health Science, 5(4):328334.

10. Dossou-Aminon, I., Loko, L.Y., Adjatin, A., Dansi, A., Elangovan, M., Chaudhary, P., Vodouhè, R., Sanni, A., (2014a). Diversity, genetic erosion and farmer's preference of sorghum varieties [Sorghum bicolor (L.) Moench] in North-Eastern Benin. Int. J. Curr. Microbiol. App. Sci., 3(10) 531-552

11. Dossou-Aminon, I., Adjatin, A., Loko, L.Y., Dansi, A., Tonapi, V., Visarada, K., Subedi, A. (2014b). Farmers' perceptions and adaptation strategies to mitigate impact of climate change scenario on sorghum production and diversity in North eastern of Benin. Int. J. Curr. Microbiol. App. Sci. 3(10) 496-509.

12. King, E. D. I.O., 2016 Impact of Reduced drudgery of women in production and pos $\mathrm{t}-$

harvest processing of small millets".MSSRF working Paper No.09. Chennai : M S Swaminathan

13. Research foundation. 20p.

14. Kombo, G.R., Dansi, A., Loko, L.Y., Orkwor, G.C., Vodouhè, R., Assogba, P., Magema, J.M. 2012. Diversity of cassava (Manihot esculenta Crantz) cultivars and its 
management in the department of Bouenza in the Republic of Congo. Genet. Resour. Crop Evol., 59(8): 1789-1803. https://doi.org/10.1007/s10722-012-9803-0

15. Loko, Y.L., Dansi, A., Agré, A.P., Akpa, N.,DossouAminon, I., Assogba, P., Dansi, M., Akpagana, K., Sanni, A. (2013). Perceptions paysannes et impacts des changements climatiques sur la production et la diversité variétale de l'igname dans la zone aride du nord-ouest du Bénin. Int. J.
Biol.
Chem.
Sci.
$7(2)$
$672-695$

https://doi.org/10.4314/ijbcs.v7i2.23

16. Macauley, H., Ramadjita, T. (2015). Les cultures céréalières : riz, maïs, millet, sorgho et blé. $31 \mathrm{p}$.

17. Mekbib, F. (2007). Infra-specific folk taxonomy in sorghum (Sorghum bicolor (L.) Moench) in Ethiopia: folk nomenclature, classification, and criteria. Journal of Ethnobiology and Ethnomedicine, 3(8): 645-663. https://doi.org/10.1186/1746-4269-3-38

18. Missihoun, A.A., Agbangla, C., AdoukonouSagbadja, H., Ahanhanzo, C., Vodouhè, R. (2012). Gestion traditionnelle et statut des ressources génétiques du sorgho (Sorghum bicolor L. Moench) au Nord-Ouest du Bénin. Int. J. Biol. Chem. Sci., 6: 1003-1018. https://doi.org/10.4314/ijbcs.v6i3.8

19. Quenum, F. J. B, Ahoton, L.E., Ezin, V., Djanta, A. (2017) Agro-morphological Variability of Maize Cultivars in South Benin. Journal of Experimental Agriculture International; 15(3): 1-19.

20. Shoo, T. A. (2011). Gender division of labour in food production and decision making power and impact on household food security and child nutrition in rural rukwa, Tanzania. Thesis. 101p

21. Thériault, V., Melinda, S., Hamza, H. (2017). How Does Gender Affect Sustainable Intensification of Cereal Production in the West African Sahel? Evidence from Burkina Faso. World Development, Vol. 92, pp. 177-191. https://doi.org/10.1016/j.worlddev.2016.12.003

22. UNFPA, 2002. World Food Summit on Food security. Reducing hunger and poverty: Women hold the key. United Nations Population Fund.

23. Van den Broek, E., (2009). Gender in development: the study of ICRISATs development initiatives for female sorghum producers in Mali

24. Vanisha, S.N., Dhaduk, J.J., Sareen, N., Shahu, T., Desai, R. (2011). Potential Functional Implications of Pearl millet (Pennisetum glaucum) in Health and Disease. J. Appl. Pharm. Sci. 1(10):62-67. 